\title{
Sobre editoriais
}

\author{
Harley E. A. Bicas
}

A editores de revistas científicas apresentam-se dois modos principais de preparar um editorial. Um é o de comentar artigos então publicados, ressaltando esta ou aquela relevância para sua distinção entre os dos demais assuntos, fazer comparações deles com aspectos do conhecimento científico, enfim, manter-se na estrita observância do conteúdo específico exposto ao leitor. Outra modalidade é a das abordagens mais abrangentes que, ainda quando relacionadas a condições direta ou indiretamente pertinentes às publicações, desviam-se de suas particularidades, procuram analisá-las sob outros ângulos.

Por vezes protagonizam comemorações, como no caso de nossa recente admissão na MEDLINE, uma condição de absoluta responsabilidade coletiva de quem prepara a revista e, como tal, de autoria compartilhada por todos. Já, entretanto, individualizada - quando igual circunstância se apresentara no caso de entrada na EMBASE, pela impossibilidade temporal desse compartilhamento. Em outros casos, os conteúdos dos editoriais subordinam-se a concepções doutrinárias, ou manifestam opiniões particulares de quem os escreve. Assuntos não faltam. As reuniões editoriais dos A.B.O., com suas diversidades temáticas, sugerem, sempre, uma grande quantidade de conhecimentos a serem comentados. Como, por exemplo, a conveniência de "personalizar" as relações da revista com seus autores e revisores, uma circunstância pedagógica de crescimento a cada um deles, mencionando, objetiva mas delicadamente: aos autores, as razões de uma rejeição de um trabalho; aos revisores, as de aceitação de outro, quando se lhe tiverem sido contrários. De fato, pessoalmente, com meu viés de professor, entendo a função editorial como evocadora de condições de aprimoramentos em todos os níveis, transcendendo ao simples dever de assegurar a divulgação de boa ciência, para se estender ao estabelecimento de propostas aos autores sobre como começar a fazê-la; ou, aos revisores, de como, equilibradamente, julgá-la.

Pois é sobre um outro editorial que hoje cabe discorrer. Ao receber o suplemento do número 4 deste volume, relativo à publicação dos resumos de trabalhos livres e painéis no XXXIII Congresso Brasileiro de Prevenção da Cegueira e Reabilitação Visual, abrindo-o na apresentação feita pelo Prof. Leiria de Andrade Neto e seus colaboradores, aí se achava outro editorial, já publicado no número 5 do volume do ano passado. Estava mais uma vez confirmada a regra de que "herrar é umano". Como poderia um texto de onze meses antes reaparecer e para onde teria viajado o que aí deveria estar?

Talvez tenha conspirado para essa ocorrência a misteriosa tessitura da natureza e da vida, que contrapõe descidas e subidas, falhas (como essa, incompreensível) a vitórias (que já foram tantas e recentes), numa lição de necessária humildade como contraponto do orgulho.

Os "acertos" foram providenciados: imediatamente acionou-se a gráfica para que se providenciasse a impressão do editorial "extraviado", para distribuição aos inscritos no XXXIII Congresso Brasileiro de Oftalmologia, quando estivessem recebendo o fascículo suplementar da revista. E como isso não devesse bastar, estamos agora reapresentando formalmente, a seguir, o mesmo editorial, tempestivamente então distribuído, mas como anexo ao suplemento da revista.

Finalmente, sem que haja consolo pela tentadora complacência de que o erro de forma é menor que o de conteúdo, fico pensando nas eventuais injustiças cometidas nas várias recusas a publicações e, ainda pior, nos possíveis erros essenciais, mas inadvertidos por revisores e editores, em matérias publicadas.
Cabe, como nota adicional, referir sobre o seleto comparecimento à sessão dos Arquivos Brasileiros de Oftalmologia nesse Congresso de Fortaleza. Apesar de concorrendo com outras 24 apresentações simultâneas, todas elas sobre matérias de aplicação altamente motivadoras (Catarata, Retina e Vítreo, Trauma Ocular, Glaucoma, Córnea e Doenças Externas, Uveítes, Cirurgia Refrativa, Estrabismos, Plásticas Oculares, Lentes de Contato, Exames Complementares, Bancos de Olhos, Neuro-oftalmologia, Visão Subnormal, Temas Livres) a reunião dos editores com autores, analistas de trabalhos e demais interessados quanto à preparação de nossa revista mostrou, mais uma vez, a importância dessa oportunidade de discussão de assuntos editoriais nos Congressos Brasileiros de Oftalmologia. Inequivocamente, nota-se a cada ano uma promissora emergência de lideranças nesse campo de ação científica que, com a confirmação de outras, já manifestas, garantem a continuidade de crescimento e a consolidação de nossas publicações. Desta feita, todo o programa foi prepara- 
do e desenvolvido sob responsabilidade dos Editores Associados. Cristina Muccioli abordou o tema "Ética em pesquisa e em publicações científicas", discutido com os presentes. Mauro Goldchmit, Mauro Silveira de Queiroz Campos e Cláudia Cristina Nagem debateram "Dúvidas sobre o aboonline", com ênfase às atuações dos revisores dos trabalhos enviados aos A.B.O. Paulo Elias Correa Dantas encarregou-se do "Gerenciamento eletrônico de artigos científicos-aboonline", com participações de Wilmar R. Silvino (ponto de vista do revisor) Gustavo Victor de Paula Baptista (ponto de vista do autor) e Cláudia Cristina Nagem (ponto de vista da secretaria editorial). Vital Paulino Costa e Samir Jacob Bechara expuseram e debateram o tema "Alternativas diante do excesso de demanda de artigos", com participações de Augusto Paranhos Júnior, José Paulo Cabral Vasconcellos e José Álvaro
Pereira Gomes. Riquíssimas contribuições e discussões comprovando a maturidade editorial a que se chegou no Brasil. Menção especial à participação de Cláudia Cristina Nagem que, como Secretária de Redação mostra uma desenvoltura cada vez maior na articulação das peças de funcionamento da revista, principalmente nesta nova modalidade, a de controle dos processos burocráticos de recepção de artigos, acompanhamento de suas distribuições para análises e de seus retornos, pelo sistema operacional disponibilizado pela rede internacional de comunicações eletrônicas (aboonline). Tanto que, ativamente, palpita, comenta e sugere aprimoramentos nessa área gerencial.

Enfim, uma reunião de excelente conteúdo de exposições, platéia selecionada e alto nível de participações nos debates. Compensou frustrações e semeia novas esperanças.

\section{CONGRESSO DE OFTALMOLOGIA E 70 CONGRESSO DE AUXILIAR DE OFTALMOLOGIA DA USP}

\section{5 a 27 de Novembro Centro de Convenções Rebouças SÃO PAULO - SP}

\section{INFORMAÇÕES:}

Creative Solution

Tel.: (11) 5575-0254 - Fax: (11) 5539-2186

E-mail: congressousp@ terra.com.br 